\title{
Perancangan Media Animasi Merintis Penemuan Sejarah Lamuri
}

\author{
Raihan Islamadina $^{{ }^{*}}$, Rizki Ubaidillah ${ }^{2}$ \\ ${ }^{1,2}$ Prodi Teknik Komputer, Universitas Serambi Mekkah, Banda Aceh \\ *Koresponden email: raihan.islamadina @ serambimekkah.ac.id
}

Diterima: 4 Oktober 2019

Disetujui: 3 Desember 2019

\begin{abstract}
Abtract
Lamreh, one of Aceh Besar regency areas, formerly had a kingdom called Lamuri Sultanate Kingdom. This Sultanate is the forerunner to the Sultanate of Aceh Darussalam. So that the history of Lamuri does not disappear, the writer is interested in providing information about the historical discovery of the kingdom of Lamuri in the form of animation. Lamuri's historical animation is designed in the form of 3dimensional object visualization with easy-to-understand voice dialogue. Animation uses 3 software in the form of Iclone, Sketchup, and Corel pro x6. This animation amounts to 10 scenes with a duration of 5 minutes 45 seconds. Hopefully, this animation can provide information to the public about the forerunner of the history of Lamuri.
\end{abstract}

Keywords: Lamuri history, animation, 3D object visualisation, Aceh Kingdom, Aceh Besar

\begin{abstract}
Abstrak
Lamreh, salah satu daerah kabupaten Aceh Besar memiliki sebuah kerajaan yang bernama Kerajaan Kesultanan Lamuri. Kesultanan ini merupakan cikal bakal kerajaan berdirinya Kesultanan Aceh Darussalam. Agar sejarah Lamuri tidak menghilang, maka penulis tertarik untuk memberikan informasi mengenai penemuan sejarah kerajaan Lamuri dalam bentuk animasi. Animasi sejarah Lamuri dirancang dalam bentuk visualisasi objek 3 dimensi dengan dialog suara yang mudah dipahami. Animasi ini menggunakan 3 software berupa Iclone, Sketchup, dan Corel pro x6. Animasi ini berjumlah 10 scene dengan durasi 5 menit 45 detik. Diharapkan, dengan adanya animasi ini dapat memberikan informasi kepada masyarakat tentang cikal bakal penemuan sejarah Lamuri.
\end{abstract}

Kata Kunci: sejarah lamuri, animasi, visualisasi objek 3D, Kerajaan Aceh, Aceh Besar

\section{Pendahuluan}

Kesultanan Lamuri merupakan sebuah kerajaan yang terletak di Lamreh, kecamatan Mesjid Raya, Aceh Besar. Kerajaan ini muncul sebelum berdirinya Kesultanan Aceh Darussalam sejak pertengahan abad ke IX masehi atau telah berdiri sejak sekitar tahun 900-an masehi. Berdasarkan sumbersumber berita dari pedagang Arab, Kesultanan Lamuri merupakan tempat pertama kali yang disinggahi para pedagang dan pelaut yang datang dari India dan Arab yang membawa ajaran Islam. Berdasarkan analisis W. P. Groeneveldt, pada tahun $1416 \mathrm{M}$ semua rakyat di Kesultanan Lamuri telah memeluk Islam. Menurut sebuah historiografi hikayat melayu, Kesultanan Lamuri merupakan daerah kedua di Pulau Sumatera yang di-Islamkan oleh Syaikh Ismail sebelum ia mengislamkan Kesultanan Samudera Pasai. Dengan demikian, dapat dikatakan bahwa Kesultanan Lamuri jelas merupakan salah satu kerajaan islam di Aceh [8].

Namun demikian banyak masyarakat yang tidak mengetahui sejarah Lamuri dan bahkan sejarah ini hampir hilang. Supaya sejarah tidak hilang, maka dibuatlah suatu video untuk memberikan informasi kepada masyarakat mengenai penemuan sejarah kerajaan Lamuri dalam bentuk animasi berbasis 3 dimensi. Adanya media animasi mampu memberikan penyampaian informasi dengan lebih mudah untuk dipahami dan dimengerti dibandingkan menggunakan lisan ataupun tulisan. Media animasi ini dapat membantu masyarakat luas tentang penemuan sejarah Kerajaan Lamuri bila difungsikan dengan tepat dan proporsional dalam penyampaian informasi dan dapat berjalan dengan efektif dan efisien.

\section{Tinjauan Pustaka \\ Animasi}

Animasi berasal dari kata to animate yang berarti menggerakkan, menghidupkan [1]. Seperti sebuah benda mati, yang digerakkan melalui perubahan sedikit demi sedikit dan teratur sehingga memberikan kesan hidup [9]. Animasi yang dulunya mempunyai prinsip yang sederhana, sekarang telah berkembang menjadi beberapa jenis, yaitu animasi 2D yang merupakan animasi paling akrab dengan keseharian kita, yang biasa disebut juga film kartun [9], animasi 3D memperlihatkan karakter yang 
semakin hidup dan nyata mendekati wujud aslinya, dan animasi tanah liat (clay animation) yang menggunakan plasticin untuk menggambarkan tokoh-tokoh animasi sesuai rangka yang khusus untuk kerangka tubuhnya [3] [7]. Film animasi tidak hanya untuk hiburan bagi anak-anak, tetapi juga dipergunakan di banyak bidang yang berisikan informasi yang disampaikan kepada penonton, seperti animasi forensik, simulasi, arsitektur, pendidikan, dan animasi hiburan dan komersial [6].

\section{Sketchup}

Perangkat lunak yang digunakan dalam rancangan animasi berupa sketchup yang merupakan software yang mempunyai fungsi dalam desain grafis model 3 dimensi di bidang teknik sipil, arsitektur, dalam pembuatan game, film, dan rancangan yang terkait didalamnya [10] [11]. Corel video studio X6 sebagai aplikasi video editing dari Ulead berupa audio (suara dan musik), animasi, video, teks, grafik, dan gambar [2] [4].

Iclon Pro 5 adalah software pembuat animasi 3D yang dilengkapi dengan berbagai model aktor digital, sampel lingkungan, efek visual dan berbagai macam fitur-fitur pendukung lain untuk membuat animasi 3D dengan mudah, cepat dan menarik [5].

\section{Storyboard}

Storyboard adalah serangkaian sketsa (gambaran dari scene), bentuk visual perancangan, audio, durasi [12] dibuat berbentuk persegi panjang yang menggambarkan suatu urutan alur cerita yang diusulkan untuk aplikasi multimedia [14]. Fungsi storyboard adalah sebagai media konsep dan ungkapan yang kreatif dalam penyampaian ide atau gagasan [13]. Pada storyboard juga seseorang bisa menambahkan arahan-arahan seperti arahan audio, letak atau arahan informasi lainnya [15].

\section{Metode Penelitian}

\section{Rancangan Animasi}

Animasi ini dirancang menggunakan software Iclone pro 5,5 dengan tahap sesuai Gambar 1. Flowchart rancangan animasi dimulai dari konsep perencanaan yang meliputi proses pra produksi, produksi, dan pasca produksi. Proses ini merupakan langkah awal sebelum membuat animasi, berupa penentuan ide yang terinspirasi dari berbagai hal, seperti pengalaman pribadi, legenda, cerita rakyat, mitos, kehidupan sehari-hari, pendidikan, perjalanan/adventure, dan lain sebagainya.

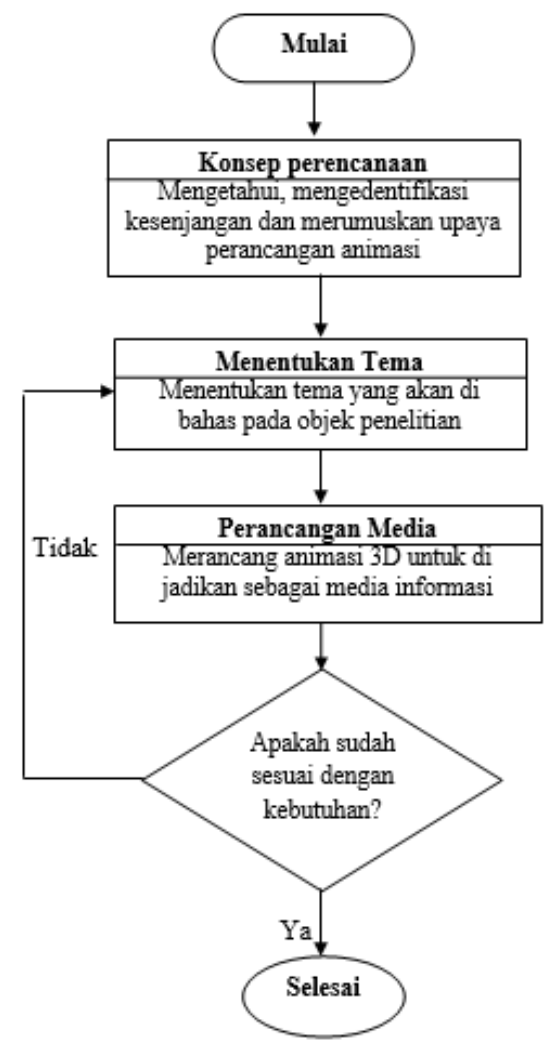

Gambar 1. Flowchart rancangan animasi 
Selanjutnya penentuan tema yang akan dibangun pada naskah cerita maupun storybord yang ditujukan kepada masyarakat luas untuk mengetahui sejarah kesultanan Lamuri di kabupaten Aceh Besar. Storyboard dalam animasi sejarah Lamuri ini memiliki jumlah scene 10 dengan durasi 5,45 menit seperti dalam Tabel 1. Terakhir, perancangan media berupa tahapan dari persiapan software-software yang dibutuhkan dalam pembuatan animasi 3D sejarah Lamuri. Adapun software yang digunakan dalam animasi ini seperti Iclone, Sketchup, Corel pro x6, dan aplikasi pendukung multimedia lainnya.

Tabel 1. Storyboard animasi sejarah Lamuri

\begin{tabular}{|c|c|c|c|}
\hline Scene & Musik & Story & Durasi \\
\hline Scene 1 & - & $\begin{array}{l}\text { Pada scene pertama ini terdapat cover sebelum animasi } \\
\text { berjalan. Cover ini berisi tentang judul dari penelitian dan } \\
\text { juga berisi semua tokoh karakter beserta objek dari } \\
\text { kerajaan lamuri }\end{array}$ & 5 Detik \\
\hline Scene 2 & $\begin{array}{l}\text { Dialog/ } \\
\text { musik }\end{array}$ & $\begin{array}{l}\text { Pada scene kedua ini menceritakan tokoh utama sedang } \\
\text { duduk di taman, tokoh utama tersebut sedang } \\
\text { membacakan sebuah buku tentang sejarah kerajaan } \\
\text { lamuri. }\end{array}$ & 25 detik \\
\hline Scene 3 & $\begin{array}{l}\text { Dialog/ } \\
\text { musik }\end{array}$ & $\begin{array}{l}\text { Pada scene ketiga ini menceritakan tokoh kedua } \\
\text { menghampiri si tokoh pertama yang sedang duduk } \\
\text { ditaman dan tokoh kedua ini menanyakan kepada tokoh } \\
\text { utama tentang buku apa yang sedang dibaca oleh tokoh } \\
\text { utama. }\end{array}$ & 18 detik \\
\hline Scene 4 & $\begin{array}{l}\text { Dialog } \\
\text { /musik }\end{array}$ & $\begin{array}{l}\text { Pada scene keempat ini menceritakan tokoh utama } \\
\text { memberi tahu kepada tokoh kedua bahwasanya buku } \\
\text { yang sedang dibaca oleh tokoh utama adalah buku } \\
\text { sejarah kerajaan lamuri. }\end{array}$ & $\begin{array}{c}11 \\
\operatorname{detik}\end{array}$ \\
\hline Scene 5 & $\begin{array}{c}\text { Dialog/ } \\
\text { musik }\end{array}$ & $\begin{array}{l}\text { Pada scene kelima ini menceritakan tokoh utama } \\
\text { menjelaskan kepada tokoh kedua tentang sejarah } \\
\text { penemuan kerajaan lamuri dan disini menampilkan } \\
\text { stopmotion objek dari kerajaan lamuri. }\end{array}$ & $\begin{array}{c}59 \\
\text { detik }\end{array}$ \\
\hline Scene 6 & & $\begin{array}{l}\text { Pada scene keenam ini tokoh utama menjelaskan kepada } \\
\text { tokoh kedua bahwa benteng indrapatra merupakan salah } \\
\text { satu benteng peninggalan dari kerajaan lamuri dan disini } \\
\text { menampilkan objek benteng indrapatra dalam bentuk } \\
\text { animasi 3D. }\end{array}$ & $\begin{array}{l}1 \text { menit } \\
3 \text { detik }\end{array}$ \\
\hline Scene 7 & $\begin{array}{l}\text { Dialog/ } \\
\text { musik }\end{array}$ & $\begin{array}{l}\text { Pada scene ketujuh ini menceritakan tentang tentang } \\
\text { penemuan makam kuno yang terletak di gampong Pande } \\
\text { Aceh Besar dan disini juga menampilkan objek dalam } \\
\text { bentuk animasi 3D. }\end{array}$ & 52 detik \\
\hline Scene 8 & $\begin{array}{l}\text { Dialog/ } \\
\text { musik }\end{array}$ & $\begin{array}{l}\text { Pada scene kedelapan ini menceritakan tentang sejarah } \\
\text { masjid tuha indrapuri yang merupakan mesjid } \\
\text { peninggalan dari kerajaan lamuri, disini menampilkan } \\
\text { video objek asli dari mesjid tersebut. }\end{array}$ & 53 detik \\
\hline Scene 9 & $\begin{array}{l}\text { Dialog/ } \\
\text { musik }\end{array}$ & $\begin{array}{l}\text { Pada scene kesembilan ini sekaligus scene terakhir } \\
\text { menceritakan tokoh kedua merasa senang karena sudah } \\
\text { mengetahui peninggalan dari sejarah lamuri yang selama } \\
\text { ini tidak banyak orang yang tau, dan disini juga tokoh } \\
\text { pertama dan kedua sama sama mengajak masyarakat } \\
\text { untuk melestarikan peninggalan sejarah yang ada di } \\
\text { Aceh. }\end{array}$ & 36 detik \\
\hline Scene 10 & musik & $\begin{array}{l}\text { Pada scene kesepuluh ini merupakan scene penutup dari } \\
\text { sebuah cerita animasi yang dijalankan. Di sini } \\
\text { menampilkan tentang nama-nama yang sudah membantu } \\
\text { dalam pembuatan animasi }\end{array}$ & 42 detik \\
\hline
\end{tabular}

\section{Hasil dan Pembahasan}

Hasil rancangan yang didapatkan pada pembuatan Animasi Merintis Penemuan Sejarah Lamuri, ditunjukkan pada gambar-gambar berikut ini.

Gambar 2. berupa tampilan cover animasi berupa scene pertama dengan durasi 5 detik ini 
menceritakan tampilan pembuka atau disebut cover. Cover ini berisi tentang judul dari penelitian dan juga berisi semua tokoh karakter beserta objek dari kerajaan lamuri.

Scene kedua dari Gambar 3, dengan durasi 25 detik ini menceritakan tokoh utama sedang duduk sendirian di taman sebelum sebelum tokoh kedua menghamprinya. Tokoh utama tersebut sedang membacakan sebuah buku tentang jejak-jejak penemuan sejarah Kerajaan Lamuri.

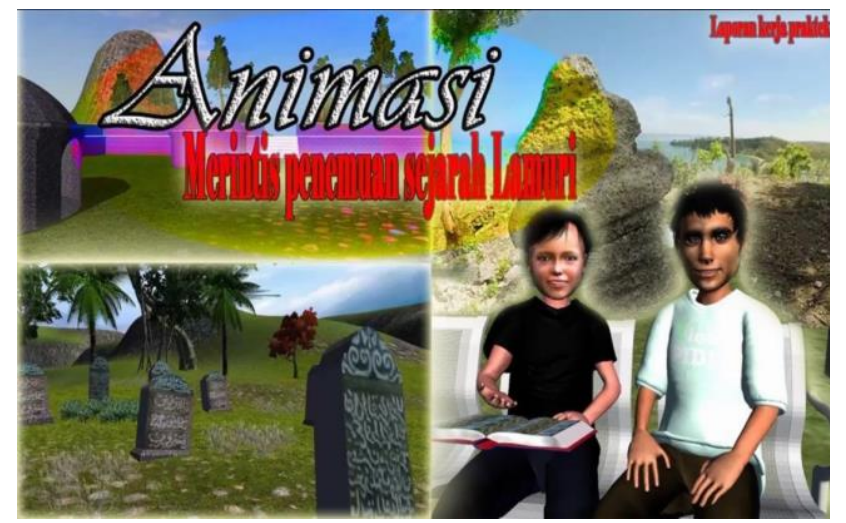

Gambar 2. Tampilan cover animasi

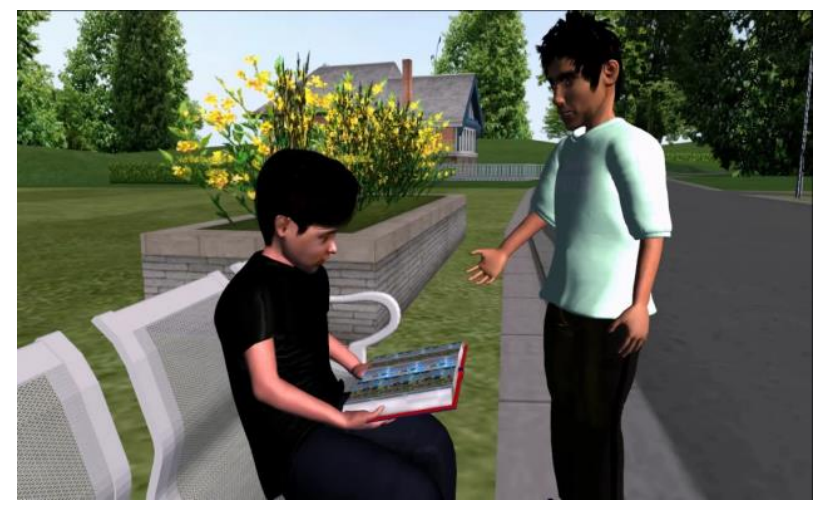

Gambar 4. Tampilan ketiga animasi

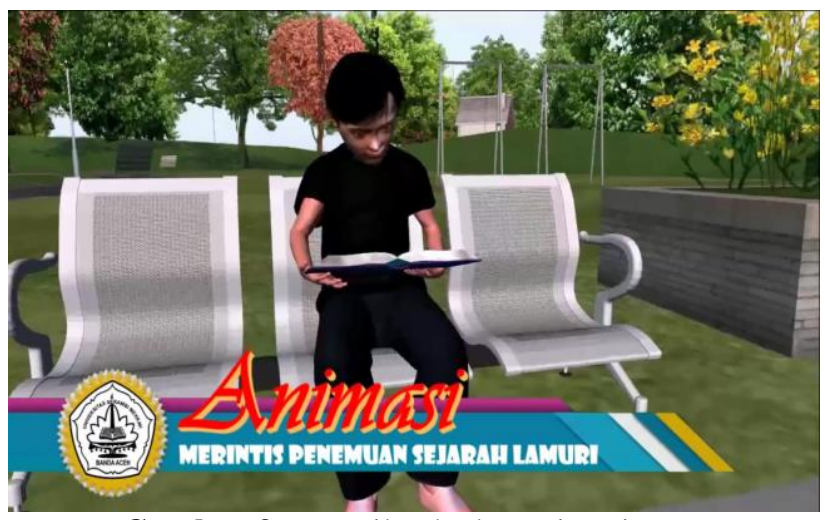

Gambar 3. Tampilan kedua animasi

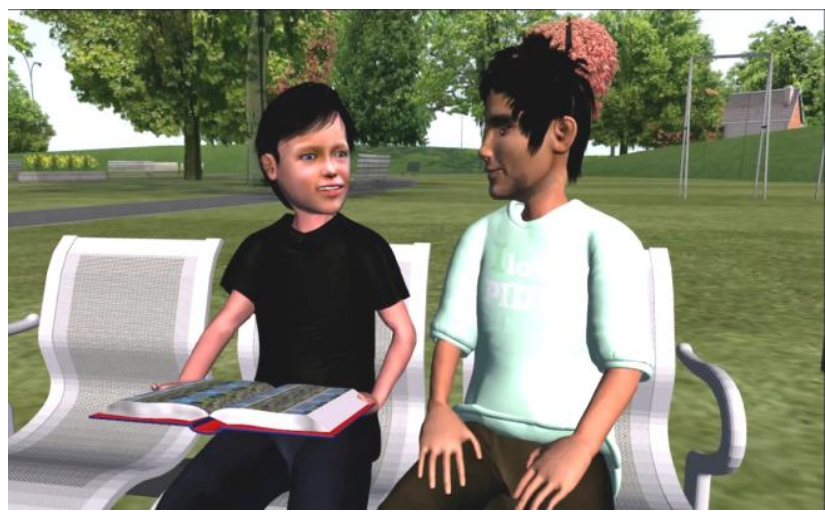

Gambar 5. Tampilan keempat animasi

Scene ketiga dari Gambar 4, dengan durasi 18 detik ini menceritakan tokoh kedua menghampiri si tokoh pertama yang sedang duduk ditaman. Tokoh kedua ini menanyakan kepada si tokoh utama tentang buku apa yang sedang dibaca olehnya. Pada scene ini terlihat percakapan antara tokoh satu dan kedua. Gambar 5 scene keempat, dengan durasi 11 detik ini menceritakan tokoh utama memberi tahu kepada tokoh kedua bahwasanya buku yang sedang dibacakan oleh tokoh utama adalah buku tentang penemuan sejarah kerajaan lamuri. Disini juga terlihat tokoh utama terlibat percakapan dengan tokoh kedua.

Gambar 6 scene kelima, dengan durasi 59 detik ini menceritakan tokoh utama menjelaskan kepada tokoh kedua tentang sejarah penemuan kerajaan Lamuri, pada scene ini menampilkan stopmotion ilustrasi objek dari kerajaan Lamuri yang ditambahkan dengan suara dialog dari google voice untuk dapat dengan mudah di pahami tentang sejarah sejarah kerajaan Lamuri.

Gambar 7 scene keenam, merupakan scene yang menceritakan tentang Benteng Indrapatra. Scene ini berdurasi 1 menit 3 detik yang menceritakan tokoh utama menjelaskan kepada tokoh kedua bahwa Benteng Indrapatra merupakan salah satu benteng peninggalan dari kerajaan Lamuri dan disini menampilkan objek Benteng Indrapatra dalam bentuk animasi 3D dan ditambahkan juga dengan suara dialog google voice.

Benteng Indra Patra yang terletak di Desa Ladong, Kecamatan Masjid Raya, Kabupaten Aceh Besar. Benteng ini memiliki sebuah benteng utama dengan ukuran 4900 meter persegi dan tiga benteng lainnya, tetapi dua diantaranya telah hancur. Situs ini didirikan oleh Putra Raja Harsya yang berkuasa di India, namun melarikan diri dari kejaran Bangsa Huna pada tahun 604 masehi. Adanya benteng ini menjadi saksi peninggalan sejarah tentang proses masuknya pengaruh hindu dari India ke Aceh. Benteng ini menjadi sebuah tanda dari wilayah segitiga kerajaan Hindu Aceh, yaitu Indra Patra, Indra Puri dan 
Indra Purwa. Benteng ini memiliki peran besar semasa kesultanan Aceh sebagai salah satu garis pertahanan dalam menghadapi Portugis dan berhasil direbut oleh Darmawangsa Tun Pangkat (Iskandar Muda). Pada masa pemerintahan Sultan Iskandar Muda (1607-1636 M), benteng ini menjadi pusat pertahanan Aceh dalam menghadang serangan dari arah laut bersamaan dengan Benteng Inong Balee, Benteng Kuta Lubok dan beberapa benteng lainnya. Benteng ini memiliki keunikan yang terletak pada susunan konstruksinya yang kokoh dengan struktur penyusun yang terbuat dari bongkahan batu gunung yang saling merekat kuat satu sama lain. Rahasianya terletak pada adonan yang dibuat dari campuran kapur, tumbukan kulit kerang, tanah liat dan putih telur yang merekatkan bongkahan-bongkahan batu gunung tersebut.

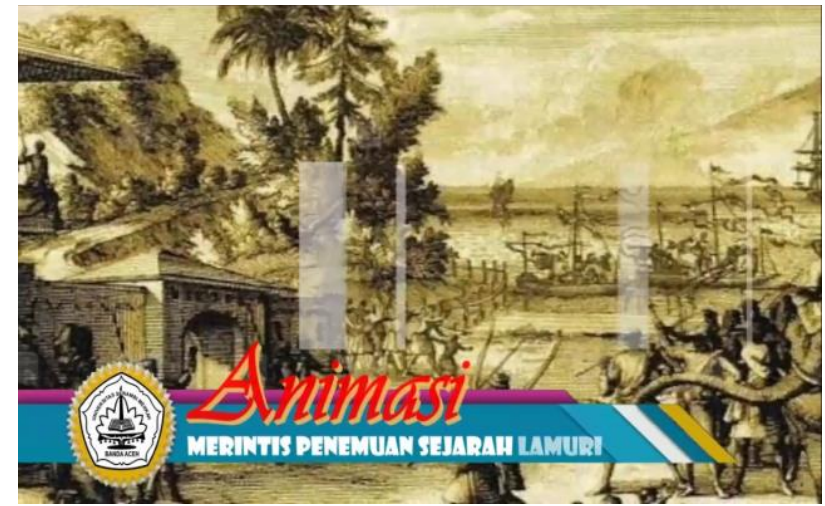

Gambar 6. Tampilan kelima animasi

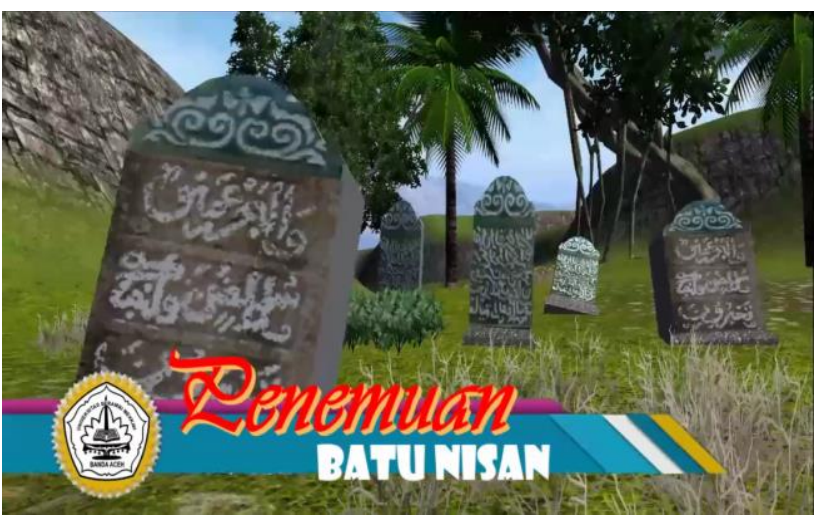

Gambar 8. Tampilan ketujuh animasi

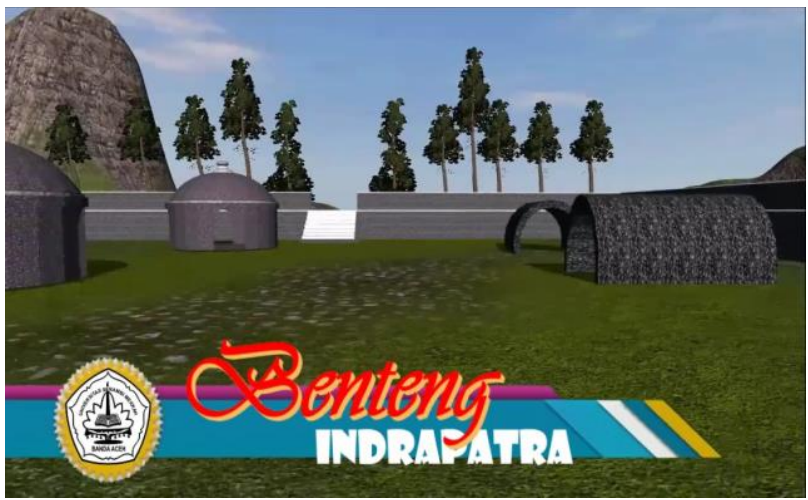

Gambar 7. Tampilan keenam animasi

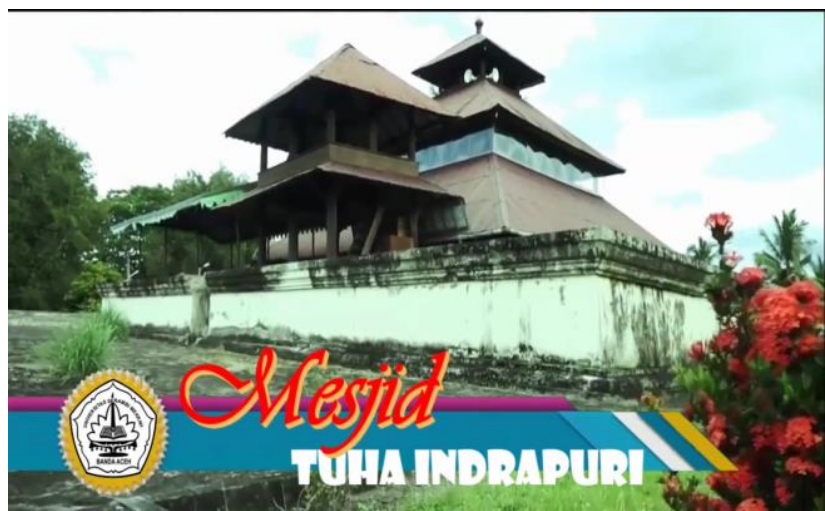

Gambar 9. Tampilan kedelapan animasi

Scene ketujuh dari Gambar 8, durasi 52 detik ini menceritakan tentang tentang penemuan makam kuno yang terletak di Gampong Pande Aceh Besar dan disini juga menampilkan pergerakan objek batu nisan dalam bentuk animasi 3D yang ditambahkan juga dengan suara dialog dari google voice. Diantara ratusan tokoh yang ditemukan terdapat delapan malik/raja, satu orang qasi dan 2 sultan kerajaan Aceh Darussalam ini dibuktikan dengan ditemukan seorang Sultan Muhammad Syah yaitu kakek buyutnya pendiri kerajaan Aceh Darussalam Sultan Ali Ri'ayat Syah Bin Samsusyah Bin Munawarsyah Bin Muhammad Syah Lamuri. Pahatan-pahatan ukiran batu nisan memiliki keunikan dengan bentuknya yang khas akan kerajaan sesuai dengan jabatannya.

Gambar 9 scene kedelapan, durasi 53 detik ini menceritakan tentang sejarah Masjid Tuha Indrapuri yang merupakan mesjid peninggalan dari kerajaan Lamuri, dan disini menampilkan video objek asli dari mesjid ditambah dengan suara dialog untuk menjelaskan sejarah Mesjid Tuha Indrapuri tersebut. Masjid Indrapuri diperkirakan dibangun sejak 1207 Hijriah atau 1618 Masehi di atas bekas reruntuhan Pura masa pra Islam. Sebuah riwayat menyebutkan bahwa Masjid Indrapuri dibangun oleh Sultan Iskandar Muda yang memimpin Kesultanan Aceh pada 1607-1636 Masehi.

Konon sebelum dibangun masjid, lokasi ini merupakan salah satu Pura yang diperkirakan sudah ada sejak abad ke 10 Masehi. Arsitektur Masjid Indrapuri cukup sederhana. Pengurus Masjid Indrapuri, Sarnadi mengatakan masjid tersebut terbuat dari batu bercampur batu dan tanah liat. Maklum, saat itu belum dikenal perekat pasir seperti semen. Saat pembangunan masjid, Sultan Iskandar Muda memasang 36 tiang penyangga bersama penopang atap. Dari tiang tersebut masih terlihat beragam bentuk ukiran 
khas masa kerajaan kuno. Bentuk atap masjid ini menyerupai piramida dengan empat atap dari bawah hingga paling pucuk yang merupakan ciri khas masjid-masjid tradisional di Aceh.

Gambar 10 scene kesembilan, durasi 36 detik ini sekaligus scene terakhir menceritakan tokoh kedua merasa senang karena sudah mengetahui peninggalan dari sejarah Lamuri yang selama ini tidak banyak orang yang tahu, dan disini juga tokoh pertama dan kedua sama-sama mengajak masyarakat untuk melestarikan peninggalan sejarah di Aceh.

Gambar 11. pada tampilan scene kesepuluh, durasi 42 detik menampilkan tentang nama pembuatan dari animasi tersebut dan juga menampilkan rasa terima kasih kepada pihak-pihak yang telah membantu dalam pembuatan animasi.

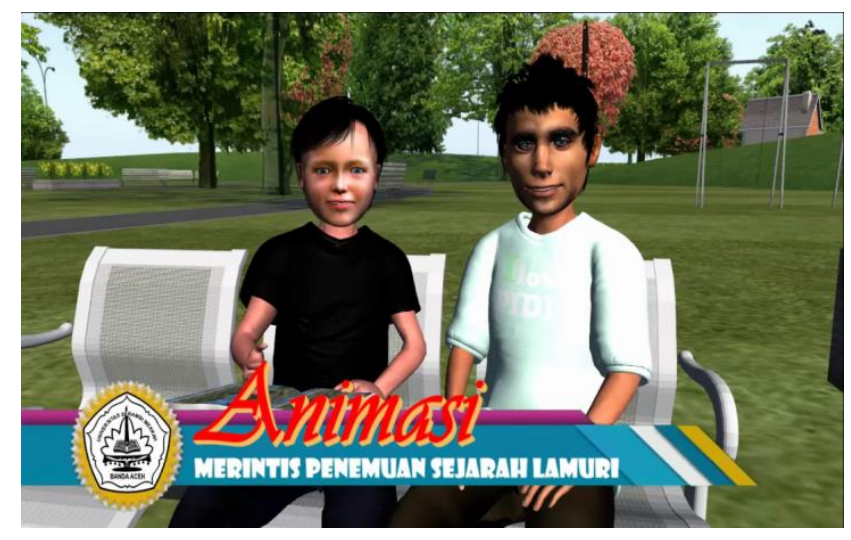

Gambar 10. Tampilan kesembilan animasi

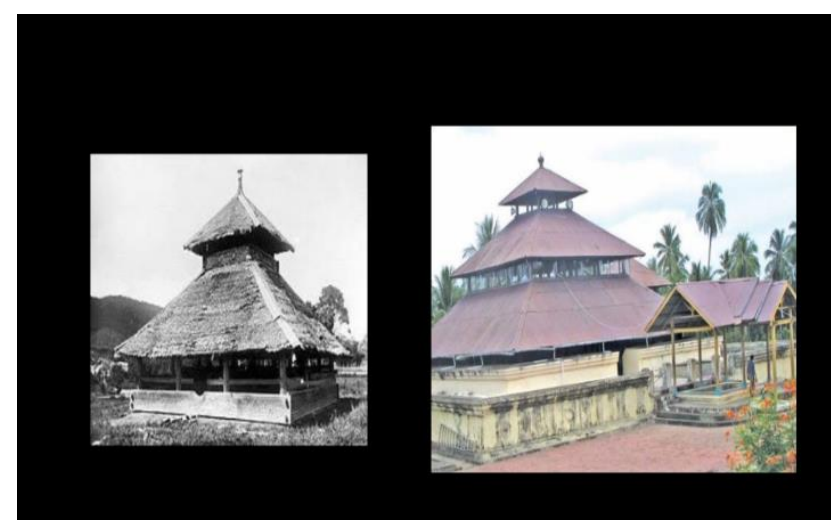

Gambar 11. Tampilan kesepuluh animasi

\section{Kesimpulan}

Berdasarkan hasil penelitian, proses pembuatan dan perancangan Animasi Merintis Penemuan Sejarah Lamuri memiliki total durasi 5 menit 45 detik. Adanya Animasi Merintis Penemuan Sejarah Lamuri dapat memberikan informasi kepada masyarakat tentang cikal bakal penemuan sejarah Lamuri yang ada di Aceh Besar dengan lebih efektif.

\section{Daftar Pustaka}

[1] Albardon. 2010. "Definisi Animasi”. Jakarta: PT. Raja Grafindo (http:// id. shvoong.com/internetand technologies/software/2040864-definisi-animasi/\#ixzz1LMaoTkFJ).

[2] Corel Video Studio X6 (http://www.bookoopedia.com/), Diakses tanggal 22 September 2018 pukul 14.00 wib.

[3] Djalle, Zaharuddin G. 2009. The making of 3D animation movie using 3D, Bandung: Informatika.

[4] Erdiwansyah, Yeni Yanti, Munawir, Raihan Islamadina. 2017. "Analisis Hibridisasi Pencarian Lokal Dengan Populasi Dalam Travelling Salesman Problem (TSP)”. Serambi Engineering, Volume II, No.4, Agustus 2017.

[5] Iclone 5 pro (www.reallusion.com), Diakses tanggal 10 Agustus (2015) pukul 11.00 wib.

[6] Henry, Samuel. 2008. "Penggunaan Film Animasi". Jakarta: Multimedia.

[7] Munir. 2009. Multimedia Konsep dan Aplikasi dalam Pendidikan. Bandung: CV Afabeta

[8] McKinnon, E.Edward. 1988. "Sejarah Tentang Lamuri”. indonesia.

[9] Prakosa, G. 2010. “Animasi Pengetahuan Dasar Film Animasi Indonesia”. Jakarta: Fakultas Film dan Televisi-Insistut Kesenian Jakarta.

[10] Sari, Indah. 2011. “Google SketchUp Perangkat Alternatif dalam Pemodelan 3D”. Tangerang: SofTech.

[11] Schreyer, Hoque. 2010. "Pengenalan Tentang Geogle Sketchup”. Bogor: Grancetak.

[12] Flafell, L. 2010. The Beginning Blender Open Source 3D Modelling, Animation, And Game Design. From http://www.it-ebooks.info, 16 mei 2013.

[13] Sunarya, L. 2016. Pengertian Storyboard. Diakses dari Jurnal Fak. Teknik, Jur. Teknik Informatika. Universitas Sumatera Utara. 
[14] Mulyono, K. M. dan Alfatta Haif. 2012. Pembuatan Game Labirin Dengan Menggunakan Blender 3D. Jurnal Dasi. Vol. 13 No. 2. STMIK AMIKOM Yogyakarta.

[15] Hidayat, Heri. 2011. Menjadi Master Photoshop Untuk Pemula dari Nol Hingga Mahir. Jakarta: Dunia Komputer. 